\title{
くシンポジウム $\mathrm{U}>$
}

\section{1. 神経幹細胞を用いた脳卒中治療}

\author{
高橋 淳 \\ 京都大学大学院医学研究科 脳秆経外科
}

Key words : 神経幹細胞, 海馬, 線維芽細胞増殖因子

(脳卒中 $24: 350-354,2002$ )

\section{1.はじめに}

「脳を守る」ということは脳神経外科医に託された使 命であるが, 従来は死にゅくニューロンの数をいかに 最小限にくい止めるかということに主眼が置かれてい た。それには血行再建を含めた脳血流の改善, ステロ イド等の投与による神経保護などが挙げられる。これ らの方法は一定の效果を上げているのであるが，特に 慢性期の状態において, 新たな神経回路の形成による 機能再生というより積極的な治療法が望まれてきた。 1980 年代にパーキンソン病患者に対する細胞移植療 法が始められ, 特に胎児黒質細胞移植はその効果が認 められているが，近年神経幹細胞の存在が明らかにな るにつれてこの細胞を用いた治療に期待が寄せられる ようになってきた，神経幹細胞を用いた機能再生の方 法として細胞移植による方法と内在性幹練胞を賦活化 する方法とがあるが（図 1)，細胞移植によって新たな 神経回路を構築することは「神経再建」と呼ぶことが 出来る。これに対し，脳内にもともと存在する神経幹 細胞からのニューロン新生を促進して神経回路を構築 することは狭義の「神経再生」と呼ぶことができる，

本稿ではおもに神経幹細胞移植に注目し，この細胞 を利用した脳卒中治療の展望について述べる.

\section{2. 神経幹細胞を通した見た脳}

「神経幹細胞」という概念が導入されたことによって 脳内の現象を改めて見直す必要がでてきた．例えば, パーキンソン病に対して行われてきた胎児中脳黒質細 胞移植を考えてみる。従来の考え方では，この移植細 胞の中に分化したあるいは未熟なドーパミン作動性 ニューロンが含まれて扔り，これらが宿主脳内に生着 すると考えられてきた。しかし，神経幹細胞にも目を 向けてみると, 移植された胎児細胞の中にはドーパミ
ン作動性ニューロン以外に神経幹細胞すなわち多分化 能・自己複製能を持つ細胞が含まれ，移植されたのち にも宿主内で增殖し移動しドーパミン作動性ニューロ ンを含む複数のタイプのニューロンやグリアに分化す ると考えられる。つまり, 移植後に脳内でみられる $\mathrm{TH}$ 陽性細胞はもともと移植細胞内に存在したものばかり でなく移植細胞内に含まれていた幹細胞が増殖し分化 したことによる TH 陽性練胞の場合もあるということ である(図 2).

神経細胞死に対する保護効果を考える場合も同様で ある.よく用いられる実験系に海馬 CA1 錐体ニューロ ンの遅発性細胞死がある. 例えば従来の考え方では， ある範囲にもともと 1,000 個あったニューロンが 2 個 になるのがあるサイトカインの脳室内投与によって 100 個になった場合, その差 98 個はサイトカインの影 響で細胞死を免れた細胞ということになる.ところが， 神経幹細胞とりわけ内在性幹細胞からのニューロン新 生という概念が導入されると，この現象の解釈はもっ と複雑になる。つまり先の 98 個のニューロンの一部あ るいはすべてが新たに生み出されたニューロンかも知 れないのである. 事実, 神経細胞保護効果があるとさ れてきた FGF-2 投与によって海馬におけるニューロ ン新生が促進されることが報告されている，虚血や外 傷などによる脳損傷時の神経細胞保護においては, 神 経細胞死を最小限に抑之るという㑡面之内在性幹細胞 からのニューロン新生を最大限に促進するという側面 の両方を考える必要があるということになる。

\section{3. 神経幹細胞の分化能}

神経機能再生を目的として細胞移植を考える場合, 移植された細胞が必要とされる夕イプのニューロンに 分化するということが前提となる．神経幹細胞は，果 たしてどのようなタイプのニューロンに分化すること 


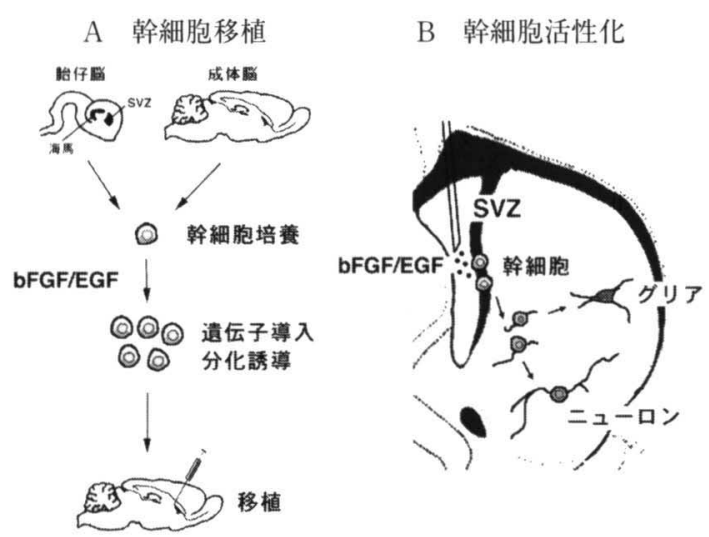

図1神経幹細胞を用いた中枢神経機能の再生 A）神経幹細胞を胎児または成体の海馬や脳室下帯か ら分離・培養し, 遺伝子導入や分化誘導の後に脳に移 植する.脳内での移動・分化によってシナプス形成や 䯣鞘形成を期待する. B ) 脳室内に FGF などのサイト カインを投与し, 内在性幹細胞からのニューロン新生, グリア新生を期待する.
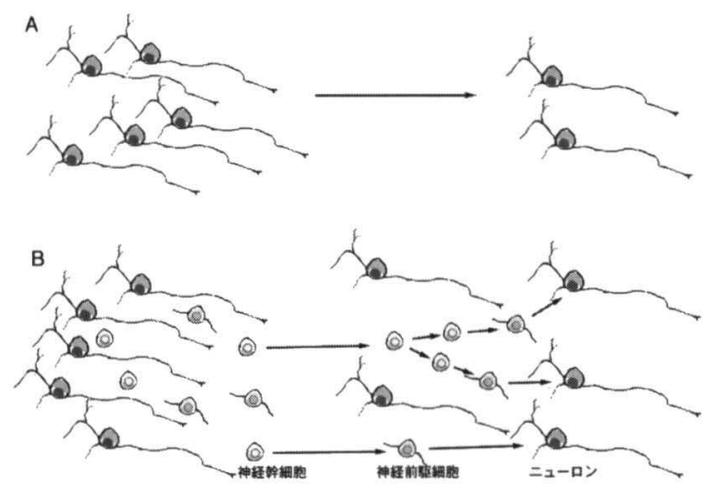

図 2 移植や神経細胞保護に対する考え方

A）従来の考え方. B) 神経幹細胞の概念を導入する

と, 神経幹細胞が増殖・分化して新たなニューロンを 生み出すという現象を考慮に入れる必要がある.

ができるのであろうか. 我々は成体ラット海馬由来神 経幹細胞を分離・培養し, さらに, ひとつの細胞から 増殖したモノクローナルな細胞株を樹立しこの細胞の 解析をおこなった . これらの細胞はレチノイン酸や NGF, BDNF, NT-3 に反応して GABA 陽性, acetylcholinesterase 陽性, tyrosine hydroxylase (TH) 陽性 あるいは calbindin 陽性ニューロンへと分化した.こ のように，神経幹細胞はひとつの細胞からであっても

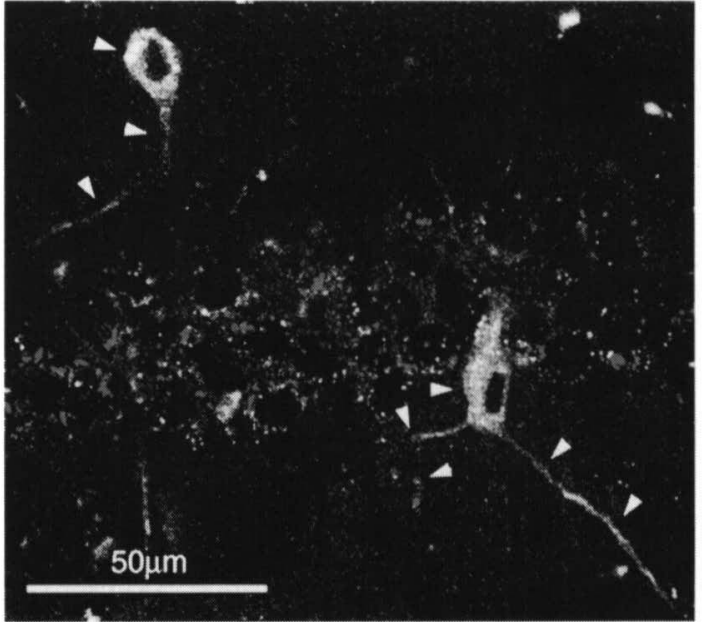

図 3 移植後の海馬 CA1 領域でみられた神経幹細胞 由来のニューロン

移植した神経幹細胞は b-gal に対する抗体で同定さ れた (矢頭)。神経突起様構造がみられると同時にシ ナプトブレビンの発現がみられ，ニューロンに分化 したものと考えられる. (文献 6 より改変)

様々なタイプのニューロンに分化する能力がある. ま た, 上記のニューロン以外にもマウス神経幹細胞から glutamate や substance P 陽性のニューロンに分化す ることが観察されており ${ }^{2)}$, 分化のコントロールや細 胞の選別を的確に行えば様々な疾患に対応できると考 えられる。

\section{4. 神経幹細胞のシナプス形成能}

脳内に移植された神経幹細胞が長期にわたって神経 機能を再生させるには, 幹細胞由来のニューロンが宿 主ニューロンとシナプスを形成し，新たな神経回路を 形成することが必要となる. その可能性を明らかにす るために, 我々は先ほどの成体ラット海馬由来神経幹 細胞を用いてそのシナプス形成能を in vitro で検討し だ).

神経幹細胞にレトロウイルスベタターを用いて GFP 遺伝子を導入し, その後, ラット胎仔海馬のグリ ア細胞層上でこの神経幹細胞を培養した.レチノイン 酸で分化誘導を行った後, BDNF, NT-3 存在下に胎仔 海馬由来初期培養ニューロンとの共培養を行った. 免 疫染色では神経幹細胞由来ニューロンの神経突起上で シナプトフィジンやシナプトブレビンといったシナプ ス小胞関連蛋白が確認され，電子顕微鏡でも未成熟な 


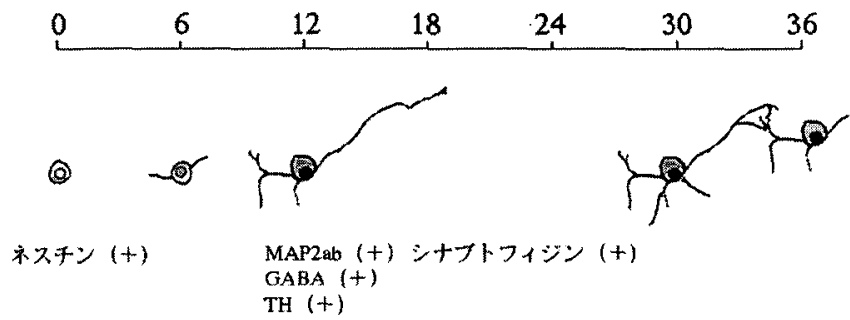

活動電值

ラット㜆发血モデル への栘㥀

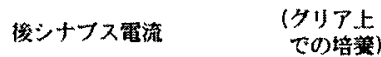

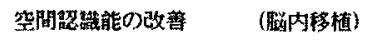

図4 成体ラット海馬由来神経幹細胞から機能的ニューロンへの分化 培養による分化誘導では, ホスチン陽性であった神経幹細胞が約 2 週間で GABAや $\mathrm{TH}$ など神経伝達物質関連蛋白を発現するようになり，さらにシナプス小胞関連蛋白 も発現するようになる、ラット海馬アストロサイト上での培養では，12〜18 日で活動 電位が認められるようになり，約 1 カ月で後シナプス電流が記録されるようになる. この細胞をラット一過性脳虚血モデルの海馬に移植すると, 後シナプス電流がみられ る時期に一致して水迷路テストでの空間認識能の改善がみられるようになる。

がらシナプス小胞や細胞膜の肥厚などのシナプス棈造 が観察された。 パッチクランプ法を用いて電気生理学 的解析を行うと分化誘導開始から 12 18 日で活動電 位が記録され，28〜35 日には後シナプス電流が観察さ れた，後シナプス電流を薬理学的に検討すると約半数 は AMPA 型グルタメイト受容体を介した興奮性電 流, 残り半数は GABA-A 受容体を介した抑制性電流 であることが分かった.

他にもラット胎仔由来神経幹細胞から誘導された ニューロンでNMDA 型グルタメイト受容体を介した 興奮性電流が観察され゙, さらに新生ラットの脳内で もシナプスを形成することが報告されている5 .これ らの結果は，移植された神経幹細胞由来のニューロン が脳内で実際にシナプスを形成し新たな神経回路を構 築することを期待させる。

\section{5. 神経幹細胞移植の脳虚血モデルに対する効果}

次に脳内での動態を検討するために上記の神経幹細 胞をラット脳内に移植した，神経幹細胞の移植実験は 数多く報告されているが，我々は一過性脳虚血モデル に注目して実験を行っだ!

側副血行路を遮断してから両側の内頸動脈を一時的 に閉塞させると海馬の CA1 領域の錐体ニューロンが 選択的に遅発性細胞死に陥る.この CA1 領域に先の海
馬由来神経幹細胞を移植し，脱落したニューロンに代 わって新たなニューロンが生着しうるかどうかを検討 した。一側につき 75,000 個の細胞を移植し，移植後 3 週間目加水迷路試験を開始して,その 10 日後に灌流 固定をして免疫染色を行った，免疫染色による観察で は，1〜3\%の細胞が CA1 領域に生着しそのうち 3〜9 \%が NeuN 陽性のニューロンへと分化していた．CA 1 に生着したニューロンは神経突起梯の構造を呈し, シナプス小胞関連蛋白を発現していた（図 3)。水迷路 試験による空間認識学習能を虚血のみのコントロール 群と比較するとCA1 に生着したニューロンが 120 個 以上のラットでは試験開始後 8〜10日後において有為 な改善が認められた。

以上の結果をまとめると，神経幹細胞は様々な夕イ プのニューロンに分化する能力をもち，脳内に移植さ れたのちも神経機能の再生をもたらすと考えられる。 そのタイムコースに注目すると，水迷路試験で空問認 識能の改善が出始めたタイミングは in vitroの実験で 後シナプス電流が記録されだしたタイミングと一致す る(図 4)。このことは移植された神経幹細胞から分化 したニューロンがシナプスを形成し新たな神経回路構 築に関与していることを示唆する。つまり，脳虚血な どによって失われたニューロンを神経幹細胞移植に よって補い，もう一度神経回路を構筑させることがで 
きる可能性があるということである.

\section{6. 内在性幹細胞の賦活化}

最近の研究で，虚血や薬敦による脳損傷時に内在性 幹細胞の賦活化機構が働いていることが明らかになっ てきている．例えば，マウスの前脳虚血モデルにおい て海騳でのニューロン新生六進が報告されている788). しかし，これらの報告では BrdU 陽性細胞の增加が見 られたのは再還流後約 1 週問前後のみであった，その 後, その神経幹細胞から分化したと思われる NeuN/ BrdU 陽性ニューロンが 26〜40 日後に増加している. また，マウスへのカイニン酸腹腔内投与や中大脳動脈 閉塞モデルでも海馬でもニューロン新生が允進するこ とが報告されているが，この場合に执いても BrdU 陽 性細胞の増加が見られたのは損傷後約 1〜2 週間後で あった9”。かつ，この効果には FGF-2 が重要な役割を 果たしている．同様に，6-OHDAを用いて黒質ドーパ ミンニューロンを脱落させたラットの線条体に TGF$\alpha$ を投与すると脳室壁に存在する神経幹細胞の增殖, 遊走によって線条体にTH陽性ニューロンが出現す る ${ }^{10)}$.この場合, 脳室壁の神経幹細胞は 4 6 日の閒增 殖し，その後線条体に向かって遊走する．また，明ら かなメカニズムは示されていないが，MPTP投与に よって黒質ドーパミンニューロンを脱落させたサルの 線条体に扔いても $\mathrm{TH}$ 陽性ニューロンの增加が報告さ れている。

つまり，脳虚血モデルやパーキンソンモデルにおい て, 脳損傷に応じて内在性幹細胞の賦活化による ニューロン新生機構が働くことは働くのであるが, そ れは急性期または要急性期に限られる。そ後には， むしろグリオーシスが起こってくる，従って，サイト カインなどを投与するタイミングが重要となるであろ う.

\section{7. おわりに}

以上のように, 従来の治療に加えて神経幹細胞を用 いた脳卒中治療の可能性がおぼらげながら見えてき た. 特に急性期においては FGF の脳室内投与などに よる内在性幹細胞の倵活化が中心となり, 病態や症状 が落ち着いた慢性期においては細胞移植が中心となろ う. 細胞移植も急性期の方が生着・分化が良いという 報告もあり，治療のタイミングは重要なポイントとな る.
脳卒中によって失われた大脳機能，特に高次脳機能 が再生するということは拡大解䣋すれば人格の維持に も関与する重大な問題である．そのためにまた新たな 倫理的問題が生じるかも知れない。また，パーキンソ ン病のように必要なニューロンのタイプ, 神経回路が 単純ではないのでどのサブタイプのニューロンがどこ に必要なのか,などを明らかにしていく必要があろう.

\section{文献}

1) Takahashi J, Palmer TD, Gage FH : Retinoic acid and neurotrophins collaborate to regulate neurogenesis in adult-derived neural stem cell cultures. J Neurobiol 38 : 65-81, 1999

2) Gritti A, Parati EA, Cova L, et al : Multipotential stem cells from the adult mouse brain proliferate and self-renew in response to basic fibroblast growth factor. J Neurosci 16 : 1091-1100, 1996

3) Toda H, Takahashi J, Mizoguchi A, et al: Neurons generated from adult rat hippocampal stem cells form functional glutamatergic and GABAergic synapses in vitro. Exp Neurol $165: 66$-76, 2000

4) Vicario-Abejón C. Collin C. Tsoulfas P, et al : Hippocampal stem cells differentiate into excitatory and inhibitory neurons. Eur J Neurosci 12 : 677688, 2000

5) Auerbach JM, Eiden MV, McKay RDG : Transplanted CNS stem cells form functional synapses in vivo. Eur J Neurosci 12 : 1696-1704, 2000

6) Toda H, Takahashi J, Iwakami N, et al : Grafting neural stem cells improved the impaired spatial recognition in ischemic rats. Neurosci Lett 316 : 9-12, 2001

7) Liu J, Solway K, Messing RO, et al : Increased neurogenesis in the dentate gyrus after transient global ischemia in gerbils. J Neurosci 18 : 7768-7778, 1998

8) Takagi $Y$, Nozaki K, Takahashi J, et al : Proliferation of neuronal precursor cells in the dentate gyrus is accelerated after transient forebrain ischemia in mice. Brain Res 831 : 283-287, 1999

9) Yoshimura S, Takagi $Y$, Harada J, et al : FGF-2 regulation of neurogenesis in adult hippocampus after brain injury. Proc. Natl. Acad. Sci. USA 98 : 5874-5879, 2001

10) Fallon J, Reid S. Kinyamu R, et al : In vivo induction of massive proliferation, directed migration, and differentiation of neural cells in the adult mammalian brain. Proc. Natl. Acad. Sci. USA 97 : $14686-14691,2000$ 


\section{Abstract \\ Treatment of stroke by using neural stem cells}

Jun Takahashi, M.D.

Neural stem cells form fuctional synapses, and differntiate into neurons in the hippocampus of the ischemic rats. The possibility of treating stroke patients by using these cells will be discussed.

(Jpn J Stroke $24: 350-354,2002)$

Key words : neural stem cells, hippocampus, fibroblast growth factor (FGF) 